\title{
Comparative studies on pasture and animal performance and parasite infestation in sheep grazing Yorkshire fog, perennial ryegrass and tall fescue pastures
}

\author{
J. HODGSON', J.H. NIEZEN ${ }^{2}$, F. MONTOSSI', F. LIU' and B.M. BUTLER ${ }^{3}$ \\ ${ }^{1}$ Department of Plant Science, Massey University, Palmerston North \\ ${ }_{2}$ AgResearch Grasslands, Flock House, Bulls \\ ${ }^{3}$ B.M. Butler Computing, PO Box 1793, Palmerston North
}

\begin{abstract}
The results are briefly reported of seven comparative studies on aspects of pasture and animal performance from pastures based on Yorkshire fog (Holcus lanatus), perennial ryegrass (Lolium perenne) or tall fescue (Festuca arundinacea) grown under adequate soil nutrient conditions (e.g., Olsen P 20-30 $\mu \mathrm{g} / \mathrm{g}$ ) and under continuous or rotational stocking by sheep. Pasture production, as measured by the stocking rate required to maintain specified sward conditions, was $2.5 \%$ greater on perennial ryegrass than on Yorkshire fog pastures, and 25\% greater on Yorkshire fog than on tall fescue. Differences in liveweight gain and wool production in weaned lambs between pastures were relatively small and inconsistent, but levels of worm egg output were lower for lambs on Yorkshire fog than on tall fescue. The use of polyethylene glycol to bind condensed tannins reduced performance slightly in lambs on Yorkshire fog and tall fescue, but not those on perennial ryegrass.
\end{abstract}

Keywords: condensed tannins, Festuca arundinacea, Holcus lanatus, lamb growth, Lolium perenne, wool production

\section{Introduction}

Yorkshire fog (Holcus lanatus L.) has been a minority species in sown grassland for many years, represented until recently by a single cuhivar, Massey Basyn, which was first released for use in 1960 (Jacques 1962). Recently, interest has been aroused in the relatively low levels of condensed tannins (CT) present in the species (Terrill et al. 1992), and the potential of these compounds for improving the efficiency of utilisation of dietary iitrogen (Waghorn et al. 1990) and for the control of jastro-intestinal parasites (Niezen et al. 1993). However, ince the 1970s (Jacques 1974; Watkin \& Robinson 974) there have been few comparative evaluations of 'orkshire fog with other species.
This paper summarises the results of a series of grazing experiments carried out at Massey University and AgResearch Grasslands from 1989-1994 on aspects of pasture production, animal performance and levels of worm parasite infestation. The experiments involved comparative studies with swards of perennial ryegrass (Lolium perenne L.) or tall fescue (Festuca arundinacea L.), mainly grown with white clover (Trifolium repens L.).

\section{Experimental designs and results}

\section{Pasture production (Experiment 1)}

Randomised 0.2 ha paddocks of Yorkshire fog (cv. Massey Basyn), perennial ryegrass (cv. Grasslands Nui) or tall fescue (cv. Grasslands Roa), each grown with white clover (cv. Grasslands Tahora) were grazed for 14 months from October 1990 to December 1991 to controlled sward surface heights of $2-3 \mathrm{~cm}, 5-6 \mathrm{~cm}$ or 9-10 cm under variable continuous stocking with dry sheep in an unreplicated experiment (Butler \& Hodgson 1993). The plots were sited on a Tokomaru silt loam soil with Olsen $\mathrm{P}$ values in the range $20-30 \mu \mathrm{g} / \mathrm{g}$ Estimates of mean stocking rates (dry sheep/ha) to maintain specified sward conditions are used here as indices of pasture production (Table 1). The results indicate that stocking rates on Yorkshire fog plots were on average about $75 \%$ of those on perennial ryegrass or tall fescue. Values for tall' fescue are misleading because, by the end of the experiment, the proportion of sown grass was only 2-12\% across sward heights in tall fescue paddocks (the replacement species being largely perennial ryegrass), compared with $42-87 \%$ and $58-70 \%$ for the Yorkshire fog and perennial ryegrass plots respectively (B.M. Butler, unpublished data).

\section{Animal performance (Experiments 2-6)}

Five comparative experiments were carried out over 4 years to evaluate animal performance, using Yorkshire fog (Massey Basyn) and either perennial ryegrass (Nui) (3 experiments) or tall fescue (Roa) (2 experiments), in each case with white clover (Tahora) (see Table 2). White clover contents were similar between swards in 
each experiment. Experiment 2 was reported earlier by Montossi et al. (1993). Continuous stocking managements were designed to maintain sward surface heights at $5-6 \mathrm{~cm}$, and rotational stocking experiments were managed at generous herbage allowance of $4-6 \%$ of LW daily. In all but experiment 2 polyethylene glycol (PEG: molecular weight 4000) dissolved in water was administered twice daily to half the animals in each treatment, in amounts designed to block the amino acid binding properties of any condensed tannins present (Barry \& Forss 1983). In experiments 3-6 all animals were drenched with levamisol (Nilverm; Cooper-Pitman-Moore NZ Ltd) at monthly intervals. Liveweight gain, carcass gain and wool growth (mid-side patch measurement) were estimated by conventional procedures.

Liveweight gains were generally higher on perennial ryegrass than on Yorkshire fog, and higher on Yorkshire fog than on tall fescue, though differences were mostly not significant (Table 3). Differences in carcass weight were smaller, but were usually significant (Table 4).

Use of PEG reduced liveweight gain by about 10\% on average in lambs on Yorkshire fog and tall fescue, though none of the individual comparisons were significant (Table 3 ), and effects on perennial ryegrass were small. The effects on Yorkshire fog and tall fescue paddocks were consistent with the tannin-binding effects of PEG in blocking the beneficial effects of plant tannins upon the efficiency of use of dietary crude protein, the small effect being indicative of relatively low concentrations of condensed tannins in the plants concerned (Waghom et al. 1990; Terrill et d. 992) Evidence from Experiment 2 (Montossi et al. 1993) and Experiment 3 (F. Montossi, unpublished) indicated the presence of condensed tannins in low concentrations in both Yorkshire fog and perennial ryegrass (range of values $0.17-0.27 \%$ in $\mathrm{DM}$ ), despite the apparent difference between species in the reaction to PEG. Concentrations in tall fescue were $0.14 \%$ in DM (F. Liu, unpublished). Although overall PEG effects were not significant for either liveweight gain (Table 3) or carcass weight (Table 4), there was usually a significant but transient advantage in early growth rate to undrenched lambs on Yorkshire fog compared with
Table 3 Effects of pasture species and use of PEG on liveweight gain of sheep $(g /$ day $)$

\begin{tabular}{|c|c|c|c|c|c|c|}
\hline \multirow[b]{2}{*}{ Species } & \multirow{2}{*}{$\begin{array}{l}\text { Use of } \\
\text { PEG }\end{array}$} & \multicolumn{5}{|c|}{ 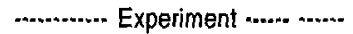 } \\
\hline & & 2 & 3 & 4 & 5 & 6 \\
\hline \multirow{2}{*}{ Yorkshire fog } & & 111 & 129 & 145 & 104 & 81 \\
\hline & + & & 113 & 142 & 92 & 72 \\
\hline \multirow[t]{2}{*}{ Perennial ryegrass } & $\cdot$ & 168 & 130 & 170 & & \\
\hline & + & & 131 & 174 & & \\
\hline \multirow[t]{2}{*}{ Tall fescue } & & & & & 80 & 79 \\
\hline & + & & & & 73 & 70 \\
\hline \multirow{3}{*}{\multicolumn{2}{|c|}{$\begin{array}{l}\text { SE mean } \\
\text { Species effect } \\
\text { PEG effect }\end{array}$}} & 18.8 & 10.0 & 9.7 & 6.2 & 5.3 \\
\hline & & NS & NS & NS & ** & NS \\
\hline & & & NS & NS & NS & NS \\
\hline
\end{tabular}

NS $\approx$ not significant

$\approx \mathrm{P}<0.01$

their drenched companions (F. Montossi and F. Liu, unpublished). This effect suggests adaptation by the animal to the presence of tannins (Barry 1985) and deserves further study.

Pasture species effects on wool growth (Table 5) were similar to those on weight gain, but in two of the trials there was a significant interaction between the effects of species and PEG caused by a positive response 
Table 4 Effects of pasture species and use of PEG on final carcass weights of sheep $(\mathrm{kg})$.

\begin{tabular}{|c|c|c|c|c|c|}
\hline \multirow[b]{2}{*}{ Species } & \multirow{2}{*}{$\begin{array}{l}\text { use of } \\
\text { PEG }\end{array}$} & \multirow{2}{*}{3} & \multicolumn{2}{|c|}{ - Experiment } & \multirow{2}{*}{6} \\
\hline & & & 4 & 5 & \\
\hline \multirow[t]{2}{*}{ Yorkshire fog } & & 16.2 & 16.3 & 15.0 & 14.4 \\
\hline & + & 16.4 & 16.2 & 14.5 & 14.1 \\
\hline \multirow[t]{2}{*}{ Perennial ryegrass } & - & 17.3 & 17.0 & & \\
\hline & + & 17.6 & 17.1 & & \\
\hline \multirow[t]{2}{*}{ Tall fescue } & & & & 14.0 & 14.2 \\
\hline & + & & & 13.9 & 14.0 \\
\hline SE mean & & 0.5 & 0.2 & 0.3 & 0.2 \\
\hline \multicolumn{2}{|l|}{ Species effect } & $\star$ & • & • & $\because$ \\
\hline PEG effect & & NS & NS & NS & NS \\
\hline
\end{tabular}

NS $=$ not significant

. $=P<0.05$

in wool growth to PEG drenching in lambs grazing perennial ryegrass. There is no obvious explanation for this effect.

\section{Worm parasite infestation (Experiment 7)}

Paddocks of single-species swards of Yorkshire fog (Massey Basyn) or tall fescue (Roa) 0.8 ha in area were maintained at constant heights of $3 \mathrm{~cm}, 5 \mathrm{~cm}$ or $8 \mathrm{~cm}$ in unreplicated treatments by continuous variable stocking of weaned lambs from December to May. Pastures received applications of $20 \mathrm{~kg} \mathrm{~N} / \mathrm{ha}$ monthly as urea. Lambs were weighed and faecal sampled fortnightly and either "suppression drenched" fortnightly with ivermectin (Ivomec, Merck Sharp and Dohme) or "trigger drenched" when any group mean egg count reached 1000 eggs/g faeces.

Lamb stocking rates were always greater on Yorkshire fog than on tall fescue paddocks at all heights (Table 6). On both pastures, final lamb live weights increased with increasing sward height (Table 6). Final weights ofsuppressively drenched lambs were $20 \%$ greater than those of trigger-drenched lambs on tall fescue $(\mathrm{P}<0.05)$, but differences on Yorkshire fog were not significant. Suppressively drenched lambs were heavier on tall fescue than Yorkshire fog $(\mathrm{P}<0.05)$, but weights of trigger-drenched lambs did not differ significantly between pasture species.

Trigger-drenched lambs were treated on 3 occasions. Peak faecal egg counts before drenching were higher on tall fescue than Yorkshire fog $(\mathrm{P}<0.05)$; and decreased with increasing sward height $(P<0.05)$ (Table 7) at 2 of the 3 times of treatment. On 2 occasions

- $=P<0.05$
Table 5 Effects of pasture species and use of PEG on clean wool growth $\left(\mathrm{mg} / 100 \mathrm{~cm}^{2} /\right.$ day) on mid-side patches.

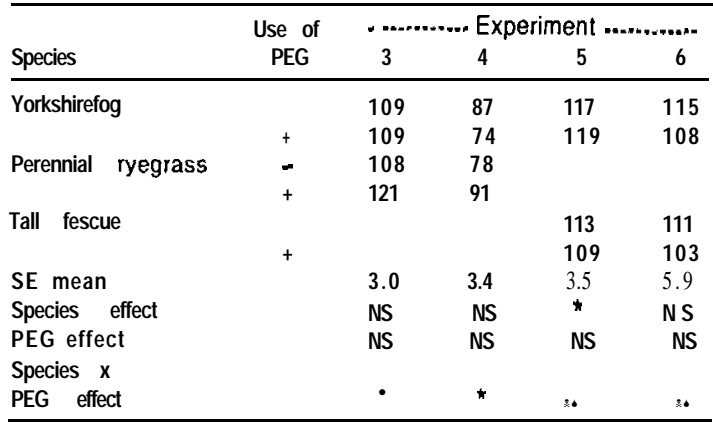

NS $=$ not significant

$\star=P<0.05$

Table 6 Effects of pasture species, sward surface height and anthelmintic drenching routine on mean stocking rate (lambs/ha) and final liveweight (LW) $(\mathrm{kg})$ of lambs. Experiment 7.

\begin{tabular}{|c|c|c|c|c|}
\hline Species & $\begin{array}{l}\text { Sward } \\
\text { height }\end{array}$ & $\begin{array}{c}\text { Stocking rate } \\
\text { (lambs/ha) }\end{array}$ & $\begin{array}{l}\text {...... Fina } \\
\text { Trigger } \\
\text { drenched }\end{array}$ & $\begin{array}{l}\text { LW }(\mathrm{kg}) \\
\text { Suppressively } \\
\text { drenched }\end{array}$ \\
\hline \multirow[t]{3}{*}{ Yorkshire fog } & $3 \mathrm{~cm}$ & 65 & 22.3 & 24.6 \\
\hline & $5 \mathrm{~cm}$ & 42 & 25.5 & 24.9 \\
\hline & $8 \mathrm{~cm}$ & 25 & 31.5 & 29.1 \\
\hline \multirow[t]{3}{*}{ Tall fescue } & $3 \mathrm{~cm}$ & 55 & 24.6 & 27.0 \\
\hline & $5 \mathrm{~cm}$ & 39 & 26.4 & 32.7 \\
\hline & $8 \mathrm{~cm}$ & 21 & 33.0 & 40.6 \\
\hline SE mean & & & 0.64 & 0.64 \\
\hline
\end{tabular}

Table 7 Effects of pasture species and sward surface height on peak faecal egg counts (eggs/g faeces) of grazing lambs before trigger drenching.

\begin{tabular}{|c|c|c|c|c|c|c|}
\hline \multirow{3}{*}{$\frac{\text { Species }}{\text { Yorkshire fog }}$} & \multirow{3}{*}{$\begin{array}{l}\text { Sward } \\
\text { height }\end{array}$} & \multirow[b]{2}{*}{.... - January ..... } & \multirow{2}{*}{\multicolumn{2}{|c|}{$\begin{array}{l}\text { - Period } \\
\ldots . . . \text { March ..... }\end{array}$}} & \multirow{2}{*}{\multicolumn{2}{|c|}{..... April ..... }} \\
\hline & & & & & & \\
\hline & & $1020 \quad(30.8) \dagger$ & 2130 & $(42.8)$ & 1390 & (35.1) \\
\hline & $5 \mathrm{~cm}$ & $430(17.9)$ & 920 & $(28.0)$ & 920 & (28.5) \\
\hline & $8 \mathrm{~cm}$ & $580(19.5)$ & 640 & $(23.6)$ & 750 & (25.3) \\
\hline \multirow[t]{3}{*}{ Tall fescue } & $3 \mathrm{~cm}$ & 1380 & 2070 & $(41.6)$ & 1200 & (31.6) \\
\hline & $5 \mathrm{~cm}$ & (32.1) & 1350 & $(29.5)$ & 590 & (20.7) \\
\hline & $8 \mathrm{~cm}$ & $680(21.9)$ & 1060 & $(31.2)$ & 1390 & (34.5) \\
\hline SE mean & & (1.37) & & (1.94) & & (2.32) \\
\hline Species effect & & $\cdot$ & & $\bullet$ & & $\therefore$ \\
\hline Height effect & & * & & * & & NS \\
\hline
\end{tabular}

tStatistical analyses carried out on square-root transformed data. Arithmetic means are shown, together with (in parentheses) means and pooled standard errors of transformed values.

NS = not significant 
than Yorkshire fog, and declined with increasing sward height on tall fescue but not Yorkshire fog (Niezen 1995).

\section{Discussion}

The results of Experiment 1 indicate the lower carrying capacity of Yorkshire fog than of perennial ryegrass pastures, under continuous stocking management, at all levels of maintained sward height and at all seasons of the year, under good soil nutrient conditions. This management procedure is somewhat artificial, but other results (B.M. Butler, unpublished data) indicate similar differences under intermittent grazing. These results do not support the evidence of Jacques (I 974), Watkin \& Robinson (1974), and Watt (1978) who showed similar or better pasture production from Yorkshire fog than from perennial ryegrass pastures under cutting management, but are consistent with the results of Morton et al. (1992) for rotationally grazed pastures. Evidence from Butler \& Hodgson (1993) suggests that the observed difference in carrying capacity may reflect a greater loss of ungrazed tissue (i.e., lower grazing efficiency) rather than any major difference in plant growthperse. In contrast, carrying capacity was higher on Yorkshire fog than on tall fescue at comparable sward heights under continuous stocking management in Experiment 7, and the results of Experiment 1 indicated clearly the limited survival of tall fescue under this management.

Evidence for differences between pasture species in animal performance was equivocal. Liveweight gains on perennial ryegrass were consistently higher than those on Yorkshire fog, though individual differences were usually modest and not significant (Table 3). Weight gains-were greater on Yorkshire fog than on tall fescue in Experiments 5 and 6, and in Experiment 5 the difference was significant. Conversely, final weights in Experiment 7 were higher for lambs grazing tall fescue than for those grazing Yorkshire fog (Table 6), and in suppressively drenched lambs the difference was significant. Differences in carcass weight were smaller in proportionate terms than differences in liveweight gain, but were usually significant (Tables 3 and 4).

The beneficial effect of Yorkshire fog in limiting the build-up of worm parasite infestation is well illustrated by the observations in Experiment 7 (Table 7), which confirm the results of an earlier trial (Niezen et al. 1993). The potential impact of this effect on lamb health and performance is indicated by the relatively small difference in liveweight gain between triggerdrenched and suppressively drenched lambs on Yorkshire fog, compared with the magnitude of the difference on tall fescue (Table 6). It should not necessarily be assumed that the control of worm parasites is simply a reflection of the presence of tannins in Yorkshire fog. Indeed, in the earlier trial (Niezen et al. 1993) worm parasite control was more effective in Yorkshire fog than in perennial ryegrass, despite the evidence of similar tannin concentrations in these two species (Montossi et al. 1993).

\section{Conclusions}

Yorkshire fog is capable of sustaining levels of sheep performance similar to those from perennial ryegrass or tall fescue. However, within the conditions of Experiments 1 and 7 (adequate soil nutrient status and continuous stocking management) Yorkshire fog clearly had a carrying capacity lower than that of perennial ryegrass but higher than that of tall fescue. Other evidence (B.M. Butler, unpublished data) demonstrates that Yorkshire fog is better suited to continuous than to intermittent stocking management. Thus, the future of Yorkshire fog in intensive farming systems appears to largely depend on exploitation of its potential advantages in the biological control of worm parasites. This potential has yet to be built into a reliable and practicable management system.

\section{ACKNOWLEDGEMENTS}

The authors thank Dr W.A.G. Charleston, Dr S.T. Morris and Dr M.J. Ulyatt for supervision, the staffs of the Department of Plant Science, Massey University and AgResearch Flock House for technical support, and the Ministry of Foreign Affairs and Trade, the Meat Research and Development Council and Hodder and Tolley Limited for funding support.

\section{REFERENCES}

Barry, T.N. 1985. The role of condensed tannins in the nutritional value of Lotus pedunculatus for sheep. 3. Rates of body and wool growth. British journal ofnutrition 54: 211-217.

Barry, T.N.; Forss, D.A. 1983. The condensed tannin content of vegetative Lotus pedunculatus, its regulation by fertiliser application, and effect upon protein solubility. Journal of the science of food and agriculture 34: 1047-1 056 .

Butler, B.M.; Hodgson, J. 1993. Effects ofmanagement on leaf growth and senescence of three contrasting grass species. Proceedings of the XVII International Grassland Congress: 147-148.

Jacques, W.R. 1962. Yorkshire fog as a pasture grass. Proceedings of the $\mathrm{New}$ Zealand Grassland Association 24: 139-150. 
Jacques, W.R. 1974. Yorkshire fog (Holcus lanatus). Its potential as a pasture species. Proceedings of the New Zealand Grassland Association 35: 249-257.

Montossi, F.M.; Hu, Y.; Hodgson, J.; Morris, S.T. 1993. Herbage intake, ingestive behaviour and diet selection in sheep grazing Holcus lanatus and perennial ryegrass swards. Proceedings of the New Zealand Society of Animal Production 54: 7 1-74.

Morton, J.D.; Bolton, G.R.; Hodgson, J. 1992. The comparative performance of Holcus lanatus and Lolium perenne under sheep grazing in the Scottish uplands. Grass and forage science 47: 143-I 52.

Niezen, J. 1995. Effects of Pasture Species on Parasitism in Lambs. Report on Project 91 MT 25/1.1, New Zealand Meat Research and Development Council 1995.

Niezen, J.; Charleston, W.A.G.; Hodgson, J.; Waghorn, T.S. 1993. Effects of four grass species on lamb parasitism and growth. Proceedings of the New Zealand Grassland Association 55: 203-206.

Terrill, T.H.; Rowan, A.M.; Douglas, G.B.; Barry,T.N. 1992. Determination of extractable and bound condensed tannin concentrations in forage plants, protein concentrate meals and cereal grains. Journal of the science of food and agriculture 58: 321-329.

Waghom, G.C.; Jones, W.T.; Shelton, I.D.; McNabb, W.C. 1990. Condensed tannins and the nutritive value of herbage. Proceedings of the New Zealand Grassland Association 51: 171-I 76.

Watkin, B.R.; Robinson, G.S. 1974. Dry matter production of 'Massey Basyn' Yorkshire fog (Holcus lanatus). Proceedings of the New Zealand Grassland Association 35: 278-283.

Watt, T.A. 1978. The biology of Holcus lanatus L. (Yorkshire fog) and its significance in grassland. Herbage abstracts 48: 195-204. 